\title{
EPIDEMIOLOGICAL PROFILE OF SNAKEBITE ACCIDENTS IN A METROPOLITAN AREA OF NORTHEAST BRAZIL
}

Polianna L.M.M. ALbUQUERQUE(1,2), Geraldo B. SILVA JUNIOR(2,3), Camilla N. JACINTO(2), Caroline B. LIMA(2), Juliana B. LIMA(4), Maria do Socorro B. VERAS(1) \& Elizabeth F. DAHER(2)

\begin{abstract}
SUMMARY
The aim of this study was to describe the epidemiological profile of snakebite accidents reported by the toxicological assistance center in Fortaleza, Ceará, Brazil. Database information on snakebite accidents was analyzed regarding the period from January 2003 to December 2011. A total of 1063 cases were found. The accidents occurred during the rainy months (March, April and May), in urban areas $(52.3 \%)$, affecting individuals younger than 50 years and predominantly among males $(70.7 \%)$. The lower limbs were the most frequently affected body area (33.7\%). Most accidents involved non-venomous snakes (76.1\%). The genus Bothrops was the main one involved in venomous accidents (83\%). It is expected that this study can be used as the substrate to improve healthcare surveillance and implementing better measures for the treatment of this population.
\end{abstract}

KEYWORDS: Snakebite accidents; Epidemiology; Bothrops; Fortaleza; Brazil.

\section{INTRODUCTION}

Snakebite accidents represent a Public Health problem in tropical areas of the globe. Envenomation occurs when the snake injects the content of its venomous glands, which means that nor all bites lead to envenomation ${ }^{19}$. Nevertheless, accidents caused by non-venomous snakes can result in important local complications, so they also deserve attention ${ }^{19}$. Most studies, however, describe only accidents caused by venomous snakes. There are approximately three thousands snakes' species and approximately $20 \%$ are venomous ${ }^{16}$.

In Latin America, there are four genera of venomous snakes that are clinically relevant: Bothrops, Crotalus, Lachesis and Micrurus ${ }^{16}$. The snakes of the Bothrops genus are responsible for most accidents due to their broad distribution and aggressive behavior, silently attacking its prey ${ }^{18}$.

The state of Ceará, with 148,920,538 square kilometers of area and $8,452,381$ inhabitants, is the third more populated state in the Northeast region of Brazil. There have been few studies on this subject in this area. GUIMARÃES et al. ${ }^{7}$ identified 1079 cases of snakebite accidents due to venomous and non-venomous snakes from 1986 to 1988 , with a mortality rate of $1.6 \%$. FEITOSA et al. ${ }^{5}$ described epidemiological aspects of these accidents in the State of Ceará in the period between 1992 and 1995. Most victims were males ( $75.6 \%$ ), aged 10 to 19 years, who frequently worked in rural areas. The lower $(67.1 \%)$ and upper limbs $(12.1 \%)$ were the most commonly affected areas. The Bothrops genus was involved in $88.3 \%$ of cases, followed by Crotalus $(10.7 \%)$, Micrurus $(0.9 \%)$ and Lachesis $(0.2 \%)$, and there were a great number of accidents in which the snake genus was not informed. Mortality was $0.7 \%$, but many cases had an ignored outcome.

Due to their high frequency and severity, snakebite accidents require cautious attention from health care services and detailed studies on their epidemiology are important to help improve health measures for this population. The aim of this study was to describe the epidemiological profile of snakebite accidents reported by the toxicological assistance center in Fortaleza, Ceará, Brazil.

\section{MATERIAL AND METHODS}

This is a retrospective study on the clinical and epidemiological characteristics of snakebite accidents reported by the Toxicological Assistance Center, Instituto Dr. José Frota, in Fortaleza, Ceará, a metropolitan area in Northeast Brazil, in the period between January 2003 and December 2011. This is the largest toxicological center in the State of Ceará.

Clinical and epidemiological aspects of these accidents were studied through the review of the National Toxic-Pharmacological Information System ("Sistema Nacional de Informações Toxicológicas" - SINITOX) regarding venomous animals' accidents. The studied parameters included:

(1) Toxicological Assistance Center, Instituto Dr. José Frota. Fortaleza, Ceará, Brazil.

(2) Post-Graduation Program in Medical Sciences, School of Medicine, Federal University of Ceará. Fortaleza, Ceará, Brazil

(3) School of Medicine, Health Sciences Center, University of Fortaleza. Fortaleza, Ceará, Brazil.

(4) Division of Internal Medicine, Hospital Geral Dr. Waldemar de Alcântara. Fortaleza, Ceará, Brazil.

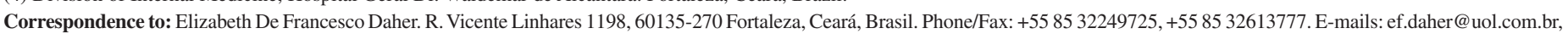
geraldobezerrajr@yahoo.com.br, pollylemos@yahoo.com.br 
ALBUQUERQUE, P.L.M.M.; SILVA JUNIOR, G.B.; JACINTO, C.N.; LIMA, C.B.; LIMA, J.B; VERAS, M.S.B. \& DAHER, E.F. - Epidemiological profile of snakebite accidents in a metropolitan area of Northeast Brazil. Rev. Inst. Med. Trop. Sao Paulo, 55(5): 347-51, 2013.

age, gender, accident circumstances, affected body area, time between the accident and the administration of anti-ophidic sera, the month in which the accident occurred, clinical manifestations, classification of the cases, snake's species and patient outcome. The identification of the snake's species was attained based on the victim's description in most cases.

Accident classification was based on the manual for diagnosis and treatment of poisonous snake accidents by the Brazilian Ministry of Health (2001).

Statistical analysis was performed through the SPSS program, version 17.0. The results were stored in a data bank and a descriptive analysis was carried out.

\section{RESULTS}

A total of 1063 cases were reported in the study period. The highest prevalence was observed in the years 2003, 2004 and 2009. The number of cases was, respectively, 153 (14.4\%), 149 (14.01\%) and $151(14.2 \%)$. The year with the lowest prevalence was 2006 , with 79 cases $(7.43 \%)$. The seasonality of the accidents is shown in Figure 1. The months between January and May were those with the highest number of cases (45.3\%). A peak in October was also observed, with 99 cases $(9.3 \%)$.

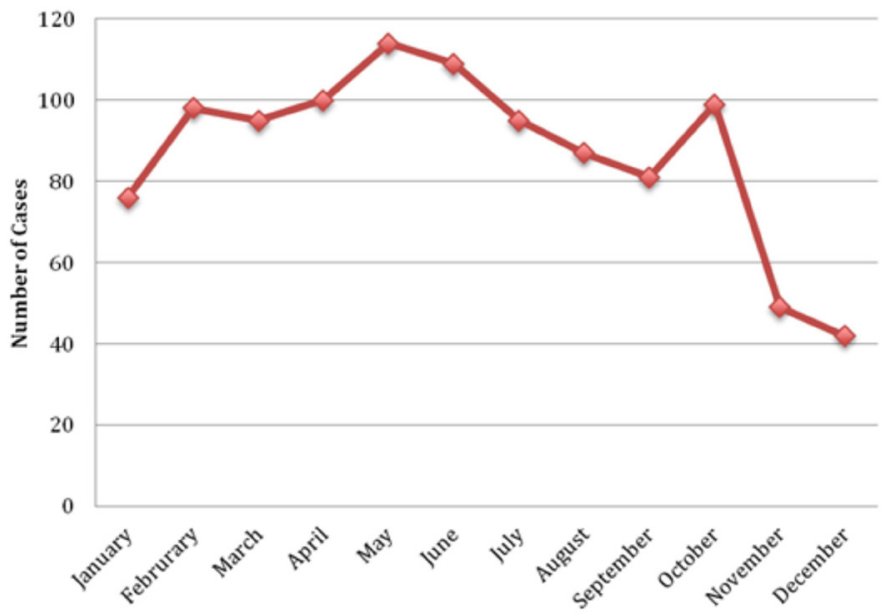

Fig. 1 - Seasonal distribution of reported cases of snakebite accidents in Fortaleza, Ceará, Brazil, in the period between January 2003 and December $2011(\mathrm{n}=1063)$.

A total of 557 accidents (52.4\%) occurred in urban areas, $462(43.5 \%)$ in rural areas and $44(4.1 \%)$ lacked such information. The city of Fortaleza was the most affected place, with 347 cases (32.6\%), as shown in Table 1.

Most victims were aged 20 to 34 years $(23.9 \%)$ and $70.7 \%$ were males (Fig. 2). Regarding the victims' occupation, only $25 \%$ of cases reported that information and the majority of individuals were farmers $(75.2 \%)$.

In 596 reported cases $(56 \%)$ there was no information about the snake's genus that caused the accident. Among the cases in which this information was reported, 211 (19.8\%) were caused by the genus Bothrops, 27 (2.5\%) by Crotalus, $14(1.3 \%)$ by Micrurus and two $(0.2 \%)$ by Lachesis. A total of $213(20.1 \%)$ accidents were caused by non-venomous snakes (Table 2). The most frequently affected body
Table 1

Demographic data from reported cases of snakebite accidents in Fortaleza, Ceará, Brazil, in the period between January 2003 and December 2011

$$
(n=1063)
$$

\begin{tabular}{lcc}
\hline Variables & Number of cases & $\%$ \\
\hline City & & \\
$\quad$ Metropolitan region of Fortaleza & 621 & 58.4 \\
$\quad$ Other regions of Ceará State & 378 & 35.5 \\
$\quad$ Ignored & 64 & 6.1 \\
Gender & & \\
$\quad$ Male & 752 & 70.7 \\
$\quad$ Female & 311 & 29.3 \\
Local of the accident & & \\
$\quad$ Rural area & 462 & 43.5 \\
$\quad$ Urban area & 557 & 52.4 \\
$\quad$ Ignored & 44 & 4.1 \\
\hline Total of cases & 1063 & 100 \\
\hline
\end{tabular}

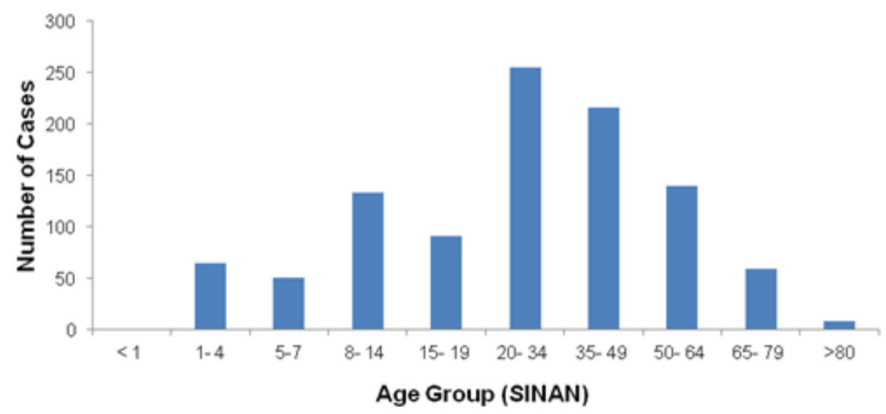

SINAN: National System of Aggravations and Notification.

Fig. 2 - Distribution according to age of cases of snakebite accidents reported by the Toxicological Assistance Center in the period between January 2003 and December 2011 $(\mathrm{n}=1063)$.

areas were the lower limbs (71.8\%), followed by upper limbs (26.6\%), head $(1 \%)$ and trunk $(0.6 \%)$. Medical care was provided, in the majority of cases, within less than 12 hours after the accident $(n=148)$, and in only six cases treatment was provided within less than one hour after the accident (Table 2). In 83 (7.8\%) out of 231 patients, the time from snakebite until treatment was greater than 12 hours.

The most frequent clinical manifestations (36.8\%) were local complications, including pain and edema, followed by hemorrhagic abnormalities (15.6\%). Acute kidney injury (AKI) was observed in 33 cases $(3 \%)$, as shown in Table 3 . Even in the accidents with nonvenomous snakes there were important local complications, such as infections and compartment syndrome. One of these cases (nonvenomous snake) developed AKI that required dialysis. Among the patients bitten by non-identified snakes, six $(1.0 \%)$ had central nervous system abnormalities and two $(0.3 \%)$ had hemorrhagic manifestations and blurred vision. 
Table 2

Descriptive data regarding the circumstances of the accidents in reported cases of snakebite accidents in Fortaleza, Ceará, Brazil, in the period between January 2003 and December $2011(n=1063)$

\begin{tabular}{|c|c|c|}
\hline Variables & Number of cases & $\%$ \\
\hline \multicolumn{3}{|l|}{ Affected body area } \\
\hline Ignored & 563 & 52.9 \\
\hline Hand & 105 & 9.9 \\
\hline Foot & 288 & 27.1 \\
\hline Upper limb & 28 & 2.6 \\
\hline Lower limb & 71 & 6.7 \\
\hline Trunk & 3 & 0.3 \\
\hline Head & 5 & 0.5 \\
\hline \multicolumn{3}{|l|}{ Type of snake } \\
\hline Ignored & 596 & 56.1 \\
\hline Bothrops & 211 & 19.8 \\
\hline Crotalus & 27 & 2.5 \\
\hline Micrurus & 14 & 1.3 \\
\hline Lachesis & 2 & 0.2 \\
\hline Non-venomous & 213 & 20.1 \\
\hline \multicolumn{3}{|l|}{$\begin{array}{l}\text { Time between the accident and } \\
\text { medical care (hours) }\end{array}$} \\
\hline Ignored & 832 & 78.3 \\
\hline $0-1$ & 6 & 0.6 \\
\hline $1-3$ & 21 & 2 \\
\hline $3-6$ & 57 & 5.4 \\
\hline $6-12$ & 64 & 0.5 \\
\hline$>12$ & 83 & 7.8 \\
\hline \multicolumn{3}{|l|}{ Outcome } \\
\hline Ignored & 5 & 0.5 \\
\hline Cured & 1028 & 96.7 \\
\hline Cured with organ dysfunction & 28 & 2.6 \\
\hline Death & 2 & 0.2 \\
\hline Total of cases & 1063 & 100 \\
\hline
\end{tabular}

Table 3

Clinical manifestations of reported cases of snakebite accidents in Fortaleza, Ceará, Brazil, in the period between January 2003 and December $2011(\mathrm{n}=1063)$

\begin{tabular}{lcc}
\hline Manifestations & Number of cases & $\%$ \\
\hline Hemorrhagic abnormalities & 75 & 15.6 \\
Central nervous system abnormalities & 120 & 7.1 \\
Local lesion & 391 & 36.8 \\
Ptosis/Diplopia & 25 & 2.4 \\
Oliguria/Anuria & 23 & 2.2 \\
Myalgia & 30 & 2.8 \\
Acute kidney injury & 33 & 3.0 \\
\hline
\end{tabular}

Regarding the classification of the accident, according to the Brazilian Ministry of Health Guidelines ${ }^{6}, 72 \%$ were classified as moderate or severe and $27.9 \%$ as mild (Table 4). Among the patients classified as severe, 19 $(20.4 \%)$ received the antivenom more than 12 hours after the accident.

Table 4

Classification and use of anti-ophidic sera in reported cases of venomous snakebite accidents in Fortaleza, Ceará, Brazil, in the period between January 2003 and December $2011(n=254)$

\begin{tabular}{lcc}
\hline Variables & Number of cases & $\%$ \\
\hline Classification & & \\
$\quad$ Mild & 71 & 27.9 \\
Moderate & 90 & 35.4 \\
$\quad$ Severe & 93 & 36.6 \\
Use of antiophidic sera & & \\
$\quad$ Ignored & 19 & 7.5 \\
Yes & 227 & 89.4 \\
No & 8 & 3.1 \\
\hline
\end{tabular}

The anti-ophidic serum was administered to $89.4 \%$ of patients in the group of venomous snakes (254) and the serum was not administered in $3.1 \%$ of cases (Table 4 ).

The majority of victims (96.7\%) achieved complete cure, $2.6 \%$ had some health limitation at the time of hospital discharge and two patients died (Table 2). Of the latter, the first patient was female, 62 years old, from the rural zone. She received 16 ampoules of antivenom and died of anaphylactic reaction after cardiorespiratory arrest unresponsive to resuscitation measures. The second patient was male, 81 years old, from the rural zone. He received 12 ampoules of antivenom and died of hemorrhagic complications.

\section{DISCUSSION}

Snakebite accidents in Brazil had a prevalence increase of $32.7 \%$ in the period between 2004 and 2009, according to data from the Ministry of Health ${ }^{20}$. There has been an increase in $32 \%$ in the notifications of accidents with venomous animals in the state of Ceará between 2007 and $2010^{21}$. In 2010, a total of 29,635 snakebite accidents were notified in our country. Eighty-five percent were caused by venomous snakes, $4 \%$ by non-venomous and $11 \%$ by non-identified snakes. The North region had the highest number of cases, 9191 , followed by the Northeast ( 8238 cases) and Southeast (6343 cases) regions ${ }^{19}$.

The incidence of snakebite accidents in Northeast of Brazil in 2010 was similar to the National incidence (15.5 accidents/100,000 inhabitants) and the state of Ceará showed a prevalence increase in the last years (9.9 accidents/100,000 inhabitants in 2010) ${ }^{22}$.

The underreporting of cases in some regions, including the Northeast, has been reported in several studies ${ }^{8,18}$ and the increase in the number of cases in the last years may reflect an improvement in the notification system in our region. The present study is one of the few in our region to describe clinical and epidemiological aspects of this type of accident. 


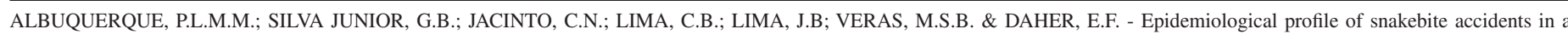
metropolitan area of Northeast Brazil. Rev. Inst. Med. Trop. Sao Paulo, 55(5): 347-51, 2013.

Accidents in urban areas were the most frequent in the present study and if we include the city of Fortaleza and its metropolitan area we will find $62.3 \%$ of the reported cases. The metropolitan area of Fortaleza, according to data from the Brazilian Institute of Geography and Statistics (IBGE), is the sixth largest in Brazil, with 3,610,379 inhabitants ${ }^{8}$. The population increase probably had had an impact on the occurrence of the snakebite accidents. The increase in domestic garbage volume contributes to the proliferation of rodents, which in turn attract snakes, favoring the occurrence of the accidents. The association between urbanization and snakebite accidents was also described in a previous study in the state of Minas Gerais ${ }^{10}$. The cases reported in urban areas require special attention, demonstrating that large cities need an adequate infrastructure to avoid snake proliferation ${ }^{11}$.

The predominance of the male gender $(70.7 \%)$ observed in the present study shows a higher exposure of these individuals to risk areas, probably linked to work activities, such as agriculture. However, there were several instances in which the place of accident was not informed. Most victims (43\%) were aged 20 to 49 years, which is the most economically active age. FEITOSA et al. ${ }^{5}$ had already described the predominance of male gender in snakebite accidents (more than $70 \%$ ), but in a younger population (10-19 years old), in the State of Ceará in the 1990s. BORGES et al. ${ }^{3}$, in a study in the Amazon region, also showed the predominance of males $(81.3 \%)$ and $72.1 \%$ of this sample was economically active. The profile of these accidents remained stable during many years and

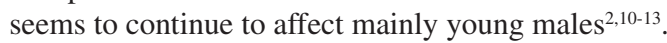

Regarding seasonality, the occurrence of snakebite accidents is associated to climate factors and an increase in human activity in rural areas. The highest incidence is observed during the months between September and March in the South, Southeast and Midwest regions of Brazil, and between January and May in the Northeast region ${ }^{6}$. Most cases occurred in the warmest and rainy months (February to May). The association between the increase in the number of accidents and rainy season was reported in other studies in Brazil ${ }^{10-13}$. An increase in the number of cases in October in our region may also be due to an increase in the volume of rain during this month, a known phenomenon that favors the cultivation of cashew nuts ${ }^{19}$.

In most studied cases, the clinical and epidemiological history allowed the identification of the type of snake involved in the accident. The genus Bothrops is responsible for the majority of accidents involving venomous snakes, varying from 70 to $90 \%$ of cases $^{9,10-13}$. The lower limbs were the most affected body area (71.8\% of informed cases), similar to the reported in other studies ${ }^{3,9,11-13}$.

The time between the accident and medical care was not informed in $78.3 \%$ of cases. Regarding the informed ones $(21.7 \%)$, we observed a delay in medical care, as $35.9 \%$ were admitted to the toxicological center for health care more than 12 hours after the accident. The long time between the accident and medical care may be responsible for the development of a more severe clinical picture $(72 \%$ of cases were classified as moderate to severe). OLIVEIRA et al..$^{13}$ showed a higher number of moderate to severe cases in the State of Paraíba, Northeast Brazil, and there was a direct association with the time between the accident and hospital admission. This association has also been found in other studies ${ }^{9,12,14,15}$. LIMA et al. ${ }^{10}$ showed, in the state of Minas Gerais, that most cases reported in that region (2002 to 2006) were classified as mild. These cases (66.5\%) showed rapid hospital admission (up to three hours after the accident). This fact correlates with the good clinical outcome.

In the present study, anti-ophidic serum was administered to approximately $21.3 \%$ of the cases and the lack of serum administration may be related to the type of snake (non-venomous). These data have also been observed in previous studies ${ }^{10}$. We observed that the serum was administered to $89.4 \%$ of cases (venomous snake cases). This fact is compatible to the severity of these cases, demonstrating that administration was carried out according to the guidelines by the Brazilian Ministry of Health ${ }^{6}$.

Regarding the clinical manifestations, we observed a predominance of local complications, at the site of the snake bite, followed by hemorrhagic manifestations. It is important to note that even in the accidents caused by non-venomous snakes, there were also important local complications. It is known, for example, that the snake of the genus Philodryas (known as "green snake", "cobra-verde" or "cobra-cipo" in Portuguese) and Clelia (known as "black snake", "muçurana" or "cobra-preta" in Portuguese), which are classified as non-venomous, can cause important local complications ${ }^{6}$. Experimental studies have shown that the Philodryas olfersii venom has hemorrhagic, proteolytic, fibrinogenolytic and fibrinolytic actions, but no anticoagulant action ${ }^{6}$. CORREIA et al. ${ }^{4}$ reported a case of Philodryas olfersii accident characterized by important local complications and anaphylactic reaction to the use of antibothropic serum, demonstrating that these accidents cannot be underestimated. Similarly, we observed one case of severe complications due to the bite of this snake, with the development of sepsis and AKI requiring dialysis. Regarding victim outcome, most of them achieved complete cure at the time of hospital discharge, but a significant percentage of cases persisted with some organ dysfunction, with renal impairment being the most frequent finding. The occurrence of kidney dysfunction due to snakebites is well described in literature. It is the main systemic complication of snakebites and occurs more frequently after Bothrops and Crotalus accidents ${ }^{17}$. There is clinical and experimental evidence showing that these accidents can directly cause kidney injury, which is the main cause of death ${ }^{2,9}$.

In summary, snakebite accidents are frequent in the state of Ceará and the toxicological assistance center has a fundamental role in the management of these victims. The epidemiological profile is characterized by a predominance of young males and the occurrence of local complications. It is important to achieve a correct diagnosis of the type of accident and the early administration of anti-ophidic serum to achieve a favorable outcome. The correct filling out of the notification form is important to provide tools to better plan health policies for the care of this population.

\section{RESUMO}

\section{Perfil epidemiológico dos acidentes por picada de cobra em região metropolitana do nordeste do Brasil}

O objetivo deste estudo é descrever o perfil epidemiológico dos acidentes ofídicos atendidos e notificados ao Centro de Assistência Toxicológica (CEATOX), em Fortaleza, Ceará, Brasil. Foram analisadas informações sobre os acidentes ofídicos relativos ao período compreendido entre janeiro de 2003 a dezembro de 2011, por meio de banco de dados. Os resultados demonstraram 1063 casos notificados 


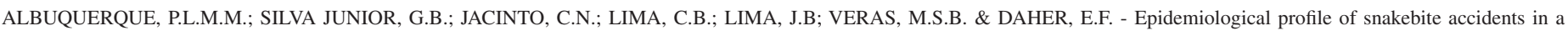
metropolitan area of Northeast Brazil. Rev. Inst. Med. Trop. Sao Paulo, 55(5): 347-51, 2013.

ao CEATOX, Ceará. Os acidentes ocorreram principalmente em meses chuvosos (março, abril e maio), em áreas urbanas (52,3\%), em uma faixa etária menor de 50 anos, acometendo predominantemente o sexo masculino $(70,7 \%)$. Os membros inferiores foram os locais mais afetados $(33,7 \%)$. A maior parte dos acidentes envolveu serpentes não peçonhentas (76,1\%). O gênero Bothrops foi o maior responsável pelos acidentes com serpentes peçonhentas (83\%). Espera-se que os dados da casuística obtida sirvam de ferramenta para o planejamento de medidas de saúde voltadas para prevenção e atendimento mais adequado da população em estudo.

\section{REFERENCES}

1. Aguiar M, Sousa Neto N, Braga C, Brito J, Silva E, Silva F, et al. Zoneamento pedoclimático para a cultura do cajueiro (Anacardium occidentale L.) no Nordeste do Brasil e Norte de Minas Gerais. Fortaleza: Embrapa Agroindústria Tropical; 2000. (Boletim de Pesquisa, n² 27, p.13).

2. Bochner R, Struchiner C. Epidemiologia dos acidentes ofídicos nos últimos 100 anos no Brasil: uma revisão. Cad Saúde Pública. 2003;19:7-16.

3. Borges C, Sadahiro M, Santos MC. Aspectos epidemiológicos e clínicos dos acidentes ofídicos ocorridos nos municípios do Estado do Amazonas. Rev Soc Bras Med Trop. 1999;32:637-46

4. Correia JM, Santana Neto PL, Pinho MS, Silva JA, Amorim ML, Escobar JA. Poisoning due to Philodryas olfersii (Lichtenstein, 1823) attended at Restauração Hospital in Recife, State of Pernambuco, Brazil: case report. Rev Soc Bras Med Trop. 2010;43:336-8.

5. Feitosa RF, Melo IM, Monteiro HS. Epidemiologia dos acidentes por serpentes peçonhentas do Estado do Ceará - Brasil. Rev Soc Bras Med Trop. 1997;30:295-301.

6. Fundação Nacional de Saúde. Manual de diagnóstico e tratamento de acidentes por animais peçonhentos. Brasília: Ministério da Saúde; 2001. p. 9-36.

7. Guimarães J, Fonseca Neto MD, Rouquayrol MZ, Lima Verde JS. Acidentes ofídicos: identifique - trate. Fortaleza: Centro de Atendimento Toxicológico; 1989.

8. Instituto Brasileiro de Geografia e Estatística (IBGE), Censo 2010. Available from: http:// www.censo2010.ibge.gov.br/dados_divulgados/index.php?uf=23

9. Lemos JC, Almeida TD, Fook SM, Paiva AA, Simões MO. Epidemiologia dos acidentes ofídicos notificados pelo Centro de Assistência e Informação Toxicológica de Campina Grande (Ceatox-CG), Paraíba. Rev Bras Epidemiol. 2009;12:50-9.

10. Lima JS, Martelli Júnior H, Martelli DR, Silva MS, Carvalho SF, Canela JR, et al. Perfil dos acidentes ofídicos no norte do Estado de Minas Gerais, Brasil. Rev Soc Bras Med Trop. 2009;42:561-4.
11. Lima AC, Campos CE, Ribeiro JR. Perfil epidemiológico de acidentes ofídicos do Estado do Amapá. Rev Soc Bras Med Trop. 2009;42:329-35.

12. Mise YF, Lira-da-Silva RM, Carvalho FM. Envenenamento por serpentes do gênero Bothrops no Estado da Bahia: aspectos epidemiológicos e clínicos. Rev Soc Bras Med Trop. 2007;40:569-73.

13. Oliveira FN, Brito MT, Morais IC, Fook SM, Albuquerque HN. Accidents caused by Bothrops and Bothropoides in State of Paraiba: epidemiological and clinical aspects. Rev Soc Bras Med Trop. 2010;43:662-7.

14. Pacheco UP, Zortéa M. Snakebites in Southwestern Goiás State, Brazil. J Venom Anim Toxins Incl Trop Dis. 2008;14:141-51.

15. Pinho FM, Zanneta DM, Burdmann EA. Acute renal failure after Crotalus durissus snakebite: a prospective survey on 100 patients. Kidney Int. 2005;1:659-67.

16. Pinho FM, Yu L, Burdmann EA. Snakebite-induced acute kidney injury in Latin America. Semin Nephrol. 2008;28:354-62.

17. Santos MF, Farani MC, Rocha PN. Insuficiência renal aguda em acidentes ofídicos por Bothrops sp. e Crotalus sp.: revisão e análise crítica da literatura. J Bras Nefrol. 2009;31:132-8.

18. Sgrignolli L, Mendes GE, Carlos CP, Burdmann EA. Acute kidney injury caused by Bothrops snake venom. Nephron Clin Pract. 2011;119:131-7.

19. Sistema de Informação de Agravos de Notificação [Internet]. Óbitos por acidentes por serpentes. Brasil, Grandes Regiões e Unidades Federadas. [cited 2012 Aug]. Available from: http:// portal.saude.gov.br/portal/saude/profissional / visualizar_texto. cfm?idtxt $=31500$

20. Sistema de Informação de Agravos de Notificação. Óbitos por acidentes por serpentes. Brasil, Grandes Regiões e Unidades Federadas. Available from: http://portal.saude. gov.br/portal/arquivos/pdf/clipping_30_07_2010.pdf

21. Sistema de Informação de Agravos de Notificação [Internet]. Incidência (100,000 hab) de casos de acidentes por serpentes. Brasil, Grandes Regiões e Unidades Federadas. 2000 a 2010. Available from: http://portal.saude.gov.br/portal/arquivos/pdf/tabela inc_casos_serpente_01_04_2011.pdf

22. Sistema Nacional de Vigilância em Saúde: relatório de situação/ Ceará. $5^{\mathrm{a}}$ edição. Brasília: Ministério da Saúde. Secretaria de Vigilância em Saúde; 2011. p. 16-17.

Received: 7 January 2013

Accepted: 18 March 2013 